\title{
Whither Chinese IR? The Sinocentric subject and the paradox of Tianxia-ism
}

\author{
Sinan Chu (1D) \\ Institute of Asian Studies, German Institute of Global and Area Studies (GIGA), Rothenbaumchaussee 32, \\ Hamburg 20148, Germany \\ Corresponding author. E-mail: sinan.chu@giga-hamburg.de
}

(First published online 25 August 2020)

\begin{abstract}
This essay critically assesses the Tianxia Theories, a line of indigenous International Relations (IR) theorizing in China organized around the concept of Tianxia ('all-under-heaven'). My goal is to tackle a seemingly prevalent issue among non-Western IR theories, that is, the indigenous scholars' subservience to state cues and often uncritical attitude toward their own ethnocentrism. To that end, I strategically target a recent contribution to this scholarship that explicitly seeks to articulate a non-ethnocentric theory: Xu Jilin's New Tianxia-ism (xin tianxia zhuyi). I first examine the main thesis of New Tianxia-ism to reveal its internal tensions. Then I examine what enables the formulation of New Tianxia-ism from a discursive perspective. I argue that a particular subject position, to which I refer as the 'Sinocentric Subject', plays an instrumental role in enabling contemporary Chinese intellectuals to think along the logics of New Tianxia-ism. The result, however, undermines the agenda to articulate an alternative theory that rectifies the ethnocentrism in IR. In conclusion, I suggest that Chinese indigenous scholarship ought to engage more critically the ideological inclination and the politics of knowledge within its own epistemic community.
\end{abstract}

Keywords: Tianxia Theories; global IR; non-Western ethnocentrism; Chinese IR

Tianxia Theories are a line of indigenous International Relations (IR) theorizing organized around the Chinese concept of Tianxia, commonly translated as 'all-under-heaven'1 or 'that which is under heaven'. ${ }^{2}$ Participated mostly but not exclusively by scholars from the People's Republic of China (PRC), this scholarship devotes its efforts to articulate an alternative theory of world politics with allegedly traditional Chinese philosophical ideas. Most converge on an idealized portrayal of China as a civilizational entity whose essence is defined by a cosmopolitan philosophy known as Tianxia-ism (tianxia zhuyi) or the 'doctrine of all-under-heaven'. Although the concept of Tianxia has been used by different figures and various

\footnotetext{
${ }^{1}$ Zhao 2019.

${ }^{2}$ Chang 2011.
}

(c) The Author(s), 2020. Published by Cambridge University Press. This is an Open Access article, distributed under the terms of the Creative Commons Attribution licence (http://creativecommons.org/licenses/by/4.0/), which permits unrestricted re-use, distribution, and reproduction in any medium, provided the original work is properly cited. 
schools of thoughts in China throughout the history, contemporary writers usually point to particular texts, for example, the writings of Xunzi (301 to $235 \mathrm{BCE}$ ), or particular historical periods, for example, the Zhou Dynasty (1045 to $265 \mathrm{BCE}$ ), as the source of their inspiration. ${ }^{3}$ Many of them explicitly argue that an international order based on Tianxia-ism would be inherently better at promoting stability and peace than the existing Westphalia international system. ${ }^{4}$ Within the broader discourse of IR theory, Tianxia Theories represent an interesting and significant strand of the mainland Chinese IR scholarship. ${ }^{5}$

The importance of Tianxia Theories is two-fold. At a pragmatic level, this indigenous discourse provides valuable insights into the elites' thinking in China. Given the opaqueness of the Chinese political process, it offers valuable cues to the study of Chinese foreign policy-making. As a critic of Tianxia-System ${ }^{6}$ - a seminal work in Tianxia Theories - William Callahan argued: '[Zhao's book's] power and influence thus emerges not necessarily from its arguments [...] but from its position in a network of debates among public intellectuals, state intellectuals and political leaders about China's role in the world as a major power.'. At a philosophical and social level, Tianxia Theories echo the call for global IR, which seeks to rectify Eurocentrism in the discipline of IR through a critical engagement with non-Western intellectual traditions. ${ }^{8}$ In this sense, Tianxia Theories offer a good opportunity for interlocutors of global IR to critically examine the merits and shortcomings of non-Western contributions. Although Tianxia Theories have yet to produce a coherent research agenda, it nonetheless represents an important moment for the indigenous scholarship ${ }^{9}$ and provides a potential basis for cross-cultural dialog about global theory. ${ }^{10}$

A large body of critical scholarship has developed in reaction to Tianxia Theories. One common thread of criticisms finds that the idea of Tianxia is inherently authoritarian and betrays a longing for a Sinocentric order resembling imperial China. Callahan, for example, writes that Tianxia presents 'a new hegemony that reproduces China's hierarchical empire for the twenty-first century. ${ }^{11}$ Similarly, Hun Joon Kim writes that many of the Tianxia System's alleged positive attributes 'such as moral and cultural leadership and voluntary submission, turn out, when viewed from the periphery, to be myths' and were in fact, 'the results of structural power. ${ }^{12}$

Despite criticisms, Tianxia Theories remain resilient among Chinese academic and political elites. This is puzzling and interesting. Chinese scholars are not

\footnotetext{
${ }^{3} \mathrm{Ge} 2015$. For an example, see Zhao 2008.

${ }^{4}$ See, for example, Sheng 1996, Zhao 2005, 2006, 2009, Yan 2011, Guo 2013, and Lu 2016.

${ }^{5}$ Recent years saw an increasing number of contributions by mainland China-based scholars to the IRT discourse. Notable studies include Zhao 2019, Qin 2018, Tang (2013, and Yan (2013. For a discussion of the development of Chinese IR, see Lu 2019, Noesselt 2015, Schneider 2014, Qin 2009, and Song 2001. For critical reviews of selected studies by Chinese scholars, see Zhang 2012, Hui 2012, and Callahan 2008.

${ }^{6}$ Zhao 2005 .

${ }^{7}$ Callahan 2008, 757.

${ }^{8}$ On global IR, see, for example, Shani 2008, Acharya and Buzan 2010, Acharya 2014, Hurrell 2016, Katzenstein 2016, Tickner 2016, Hellmann and Valbjørn 2017, Turton and Freire 2017, Eun 2018, and Ling and Chen 2018.

${ }^{9}$ Noesselt 2012 .

${ }^{10}$ Jenco 2017.

${ }^{11}$ Callahan 2008, 750.

${ }^{12}$ Kim 2016, 75.
} 
unfamiliar with the critical theory's insight into the politics of knowledge. Edward Said's Orientalism and Culture and Imperialism as well as Michael Hardt and Antonio Negri's Empire, among others, have been widely read by scholars since their introduction to mainland China in the 2000s. ${ }^{13}$ In fact, writers in China made reference to the notion of 'epistemic colonialism' when justifying the need for an alternative IR theory based on non-Western (Chinese) experience and perspectives. ${ }^{14}$ Yet, even those who have taken an anti-colonialist stance could not resist the temptation to flirt with the concept of Tianxia in one way or another. How do we explain the resilience of Tianxia Theories in contemporary China? Exiting studies on Chinese IR tend to approach this question from either a sociological or a cultural perspective. Although they offer valuable insight, they fail to critically appraise Chinese IR as an intellectual phenomenon. If global IR is about reimagining IR as a global discipline through a meaningful 'two-way' dia$\log ,{ }^{15}$ then we should engage Tianxia Theories on an epistemic level to understand its appeal to Chinese scholars and intellectuals at large.

To that end, this paper asks: how do the proponents of Tianxia Theories reconcile the internal incoherence and logical inconsistencies of their theories? Drawing on the theory of subject, ${ }^{16}$ in this paper I offer a critical analysis of Tianxia Theories by interrogating the subject-position that provides a logic of justification. Empirically, I focus on the case of New Tianxia-ism - a later contribution to Tianxia Theories by the Shanghai-based scholar Xu Jilin who attempts to reinvent Tianxia-ism as a kind of Chinese cosmopolitanism. The discussion proceeds in five steps. I first review the latest literature on global IR and Tianxia Theories to justify the need for a critical appraisal of the later. In the second step, I present the main tenets of New Tianxia-ism. In the third step, based on an assessment of the argument on its own terms, I argue that New Tianxia-ism fails at its promise to deliver a non-ethnocentric theory. In the fourth step, I explain its failure by problematizing the implicit subject-position of New Tianxia-ism, which I term as the 'Sinocentric Subject'. Linking this point with the broader context of contemporary China, I argue that the Sinocentric Subject helps to shed light on the paradox of Tianxia Theories as a non-Western contribution to global IR and a contemporary Chinese intellectual current. In the fifth and last step, I propose that IR scholars championing non-Western theories should engage more critically the ideological inclination and the politics of knowledge production in the non-West, especially the historical relationship between center and periphery in their respective country or region.

\section{Global IR, non-Western ethnocentrism, and Tianxia theories Resilience of non-Western ethnocentrism in global IR}

The objective of global IR, as formulated by Amitav Acharya in his introduction to the International Studies Review's 2016 President Issue, is to 'challenge IR's existing

\footnotetext{
${ }^{13} \mathrm{Ge} 2015$.

${ }^{14}$ See, for example, Zhuang 2005, Zeng 2010, and Zheng 2011.

${ }^{15}$ Acharya and Buzan 2010, Acharya 2014.

${ }^{16}$ Althusser 1994, Epstein 2011.
} 
boundary markers set by dominant American and Western scholarship and encourage new understandings and approaches to the study of world politics'. ${ }^{17}$ During the past decade or so, the field of IR has witnessed a flourishing of theorizing efforts based on non-Western intellectual traditions. Although this no doubt increased the diversity of the discipline, it also reveals a number of problems. One particularly prevalent issue among non-Western contributions to global IR is the indigenous scholars' subservience to state cues ${ }^{18}$ and often uncritical attitude toward their own ethnocentric ideologies, ${ }^{19}$ as well as the tendency to re-nationalize instead of internationalize IR. ${ }^{20}$ Consequently, later discussions have highlighted the need to readjust the agenda of global IR so to avoid either 'subjugating marginalized perspectives or engaging in a narcissistic turf war $^{21}$ and to promote instead genuine, meaningful, 'inter-national' dialogues. ${ }^{22}$

Tianxia Theories offer us a good candidate to investigate the cause for persistent ethnocentrism in non-Western IR. Since the early 2000s, a large body of critical scholarship on Tianxia Theories has emerged, highlighting a number of problematic traits that undermine their theoretical value and/or contribution to global IR. These include (1) selective and arbitrary reading of the Chinese philosophy and history, ${ }^{23}$ (2) unsubstantiated or exaggerated claim of the Chinese culture's pacifism, ${ }^{24}$ (3) uncritically prioritizing the 'Chinese experience' in theory building, ${ }^{25}$ (4) celebrating hierarchy and authoritarianism, ${ }^{26}(5)$ deemphasizing the patriarchal legacy in Confucianism, ${ }^{27}$ (6) implicit racism toward ethnic minorities, ${ }^{28}(7)$ projection of 'racial sovereignty' overseas, ${ }^{29}$ (8) rigid adherence to a 'West vs. non-West' binary, ${ }^{30}$ (9) advocating a Sinocentric world order, ${ }^{31}$ and (10) serving as a cover for Chinese nationalism. ${ }^{32}$

Interestingly, although these problems have been widely discussed both in and outside China, Tianxia-ism remains popular in the Chinese IR discourse. How do we explain the resilience of Tianxia Theories? Existing studies on Chinese IR follow either a sociological approach or a cultural approach. Callahan, ${ }^{33}$ for example, attributes the salience of Zhao's Tianxia-System to its ability to speak to the ongoing nationwide debate among public intellectuals, state intellectuals, and political leaders about China's role in the world as a major power.

\footnotetext{
${ }^{17}$ Acharya 2016, 5 .

${ }^{18}$ Tickner 2008, 745.

${ }^{19}$ Tsygankov and Tsygankov 2010, 678.

${ }^{20}$ Acharya and Buzan 2017, 342.

${ }^{21}$ Eun 2018, 438.

${ }^{22}$ Hellmann and Valbjørn 2017, Valbjørn 2017.

${ }^{23}$ Chang 2011, Ge 2015.

${ }^{24}$ Hui 2012, Kelly 2012, MacKay 2019.

${ }^{25}$ Zhang 2011, Lu 2019.

${ }^{26}$ Callahan 2008, Zhang 2012, Schneider 2014.

${ }^{27}$ Blanchard and Lin 2016.

${ }^{28}$ Callahan 2008.

${ }^{29}$ Gonzalez-Vicente 2016.

${ }^{30}$ Callahan 2008, Kim 2016.

${ }^{31}$ Chen 2011, Cunningham-Cross 2012, Shih 2012, Cunningham-Cross 2014, Babones 2017.

${ }^{32}$ Schneider 2014, Zheng and Wu 2014.

${ }^{33}$ Callahan 2008, 757-58.
} 
Kristensen and Nielsen draw on Randall Collins' sociological theory of knowledge ${ }^{34}$ and argue that the Chinese IR debate can be understood as a product of the internal academic network in China, the external geopolitical shift, as well as China's social and political development. ${ }^{35}$ Chang, on the other hand, suggests that there is a general social-psychological inclination among Chinese intellectuals to 'present something Chinese to counter the West' that led them to produce 'chinoiserie theories rather than sound ones. ${ }^{36}$ Similarly, Lu Peng observes that there is 'an epistemological inclination which prefers Chinese to non-Chinese experience in knowledge making and evaluation' in the Chinese IR movement. ${ }^{37}$

Insightful as they are, these studies overlook an important aspect of contemporary Chinese IR discourse, namely, the resilience of Tianxia Theories as an intellectual phenomenon. In other words, those aforementioned accounts do not explain how the proponents of Tianxia Theories themselves make sense of their own theories, or how they reconcile those incoherence and inconsistencies that the debate has laid bare. Equally importantly, they also do not tell us whether and how Chinese intellectuals could tackle and move beyond those issues, given the sociocultural conditions of today's China as they identified and described. Incidentally, both above questions are important for advancing the 'two-way dialogue' urgently required for the global IR project to go forward. If we are to avoid relegating non-Western IR to a status of proto- or underdeveloped theories or treating them as over-determined by their respective sociocultural circumstances, then instead of concluding that 'some Chinese intellectuals are too keen to make chinoiserie theories rather than sound ones, namely, theories with internal coherence and logical consistency, ${ }^{38}$ our task should be precisely not to dismiss those theories as such - that is, incoherent and inconsistent - but to take them seriously and inquire in a critical yet sympathetic manner: how do the proponents of Tianxia Theories themselves reconcile the internal incoherence and logical inconsistencies?

\section{A critical analysis of Tianxia Theories: Xu Jilin and New Tianxia-ism}

Answering this question requires a more engaging approach, one that resembles Ashis Nandy's 'critical insider' perspective, ${ }^{39}$ that asks questions about the enabling intellectual conditions behind the resilience of Tianxia Theories. More specifically, I seek to reveal, problematize, and critique the kinds of background knowledge, assumptions, and beliefs which make thinking along the logic of Tianxia Theories possible in the first place. To do so, I draw on Althusser's concept of interpellation $^{40}$ and Epstein's discussion on the distinction between subjectivity and subject-position $^{41}$ to examine how ethnocentrism perpetuates in Tianxia Theories through the adoption of a particular subject-position - the 'Sinocentric

\footnotetext{
${ }^{34}$ Collins 1998, 2000, 2002.

${ }^{35}$ Kristensen and Nielsen 2013.

${ }^{36}$ Chang 2011, 39.

${ }^{37} \mathrm{Lu} 2019,154$.

${ }^{38}$ Chang 2011, 39.

${ }^{39}$ Nandy 1987.

${ }^{40}$ Althusser 1994.

${ }^{41}$ Epstein 2011.
} 
Subject' - by contemporary Chinese intellectuals. Theoretically, my analysis is based upon the critical constructivist insight that discourse is capable of producing reality by constituting subjects, objects, and interpretive dispositions. ${ }^{42}$ By asking 'how could it be possible to see Tianxia Theories as coherent and consistent', I am problematizing the very possibility behind a particular decision - in this case, embracing a logically incoherent and inconsistent theory. ${ }^{43}$

However, I do not attribute the basis of such possibility to the concept of subjectivity. Instead I consider it important to distinguish between 'subjectivities' and 'subject-positions'. Subjectivity, as Epstein argued, 'is a much more extensive, and consequently unwieldy, category, where all the hyper-individualized characteristics of identity are relegated'. ${ }^{44}$ In contrast, subject position 'refers to a position within a discourse' which can be analytically approached as a discursive phenomenon. ${ }^{45}$ This distinction is important for the present study because the resilience of Tianxia Theories in contemporary China does not exist as an isolated instance. Writers that elaborate their theories based on the notion of Tianxia come from a variety of backgrounds. As much as language shapes our experience in significant ways, these individuals are just like any other people whose subjectivities involve not only socially constructed identities, but also all sorts of idiosyncratic elements such as desires and bodily affects non-reducible to language. ${ }^{46}$ Thus, I make no claim that I am able to access - not to mention analyze and critique - the subjectivities of those writers. In contrast, subject positions are more relevant and productive for my purpose. When proponents of Tianxia Theories derive their theories from the concept of Tianxia, they presumably assume a particular subjectposition which allows them to reconcile the internal incoherence and inconsistency and see their theories as logically sound. It is their subject-position that I am interested in examining and critique. Accordingly, I ask the following questions: (1) how is the particular subject-position constructed so as to make possible its formulation, and (2) how does the construction of this particular subject-position foreclose the possibility of Tianxia Theories to offer a truly non-ethnocentric theory of world politics?

Empirically, rather than surveying the entire literature of Tianxia Theories, I strategically target a recent contribution to this scholarship that explicitly seeks to articulate a non-ethnocentric theory. This gives me analytical leverage because it allows me to examine a candidate theory whose author was already aware of the issue of ethnocentrism in IR theorizing and actively tried to articulate a 'better' alternative. In other words, my choice represents a case of Tianxia scholarship whose theoretical discussion offers us likely the most direct access to the tensions within the logic of Tianxia Theories, as its author has made it his mission to construct a version of Tianxia Theory based on an explicit rejection of ethnocentrism that he saw in Tianxia-ism as commonly understood. Specifically, I focus on Xu Jilin's New Tianxia-ism, a proposal that claims to reorganize the international

\footnotetext{
${ }^{42}$ George and Campbell 1990, Doty 1993, Milliken 1999, van de Wetering 2017.

${ }^{43}$ Doty 1993, 298.

${ }^{44}$ Epstein 2011, 17.

${ }^{45}$ Ibid.

${ }^{46}$ Ibid.
} 
system based on the 'overlapping consensus' of different cultures beyond the nation-state horizon. ${ }^{47}$

A scholar of Chinese history and a well-known public intellectual, Xu Jilin has long engaged in critiques of political Confucianism, Chinese nationalism, and ethnocentrism in general. ${ }^{48}$ Different from those Chinese IR scholars more familiar to the Western audience such as Qin Yaqing or Yan Xuetong, Xu is not one of a 'theorizer within established Western theoretical traditions', nor a 'native informant presenting empirical material from their own country' or a 'quasi-official representing a perspective from their country'. ${ }^{49}$ Rather, Xu represents a nativist theorist who attempts to articulate a theory of IR based on Chinese historical experience and philosophical ideas, yet who does so without the aim of either repudiating epistemological universality ${ }^{50}$ or making obvious foreign policy prescriptions to the Chinese government. ${ }^{51}$ His writings have been introduced to the western audience through translations by Geremie R. Barmé, Gloria Davies, and David Ownby since the early 2000s. ${ }^{52}$ Although Xu Jilin is not the only one who draws from the discursive reservoir of Tianxia-ism for his intervention in the discussion about China's role in the world, Xu's New Tianxia-ism warrants special attention for my purpose because of the intellectual profile of its author and the intellectual tradition that he represents in contemporary China.

Among various strands of Chinese IR theories, Zhao Tingyang's Tianxia-System - elaborated through his 2005 monograph and several essays - is often regarded as the representative of Tianxia Theories. Since its publication, there have been a number of analyses ${ }^{53}$ and exchanges between its author and the critics. ${ }^{54}$ Many commentators have faulted Zhao for his implicit Sinocentrism and preference for authoritarianism. Although Zhao has repeatedly rejected those allegations, he never clearly stated his rejection of those ideas per se. Instead, he has either downplayed or denied the existence of ethnocentrism in ancient China. ${ }^{55} \mathrm{He}$ also voiced support for 'order' or 'the state of governed' (zhi) - as opposed to 'lack of order' or

\footnotetext{
${ }^{47} \mathrm{Xu} 2015$.

${ }^{48}$ See, for example, Xu 2006, 2012a, 2013a. For a list of his writings in Chinese, see Xu Jilin's personal webpage on Aisixiang, http://www.aisixiang.com/thinktank/xujilin.html, accessed 20th January 2020.

${ }^{49}$ Kristensen 2015.

${ }^{50}$ Makarychev and Morozov 2013, 346.

${ }^{51}$ Kristensen 2015, 648.

${ }^{52}$ See, for example, Xu 2000, 'The fate of an enlightenment: twenty years in the Chinese intellectual sphere (1978-98)' translated by Geremie R. Barmé and Gloria Davies and included in the December 2000 issue of East Asian History, Xu 2019 "I Am a Child of the Nineteenth Century': The Last Twenty Years of Wang Yuanhua's Life (2008)' translated by David Ownby and included in Voices from the Chinese Century: Public Intellectual Debate from Contemporary China (edited by Timothy Creeks, David Ownby, and Joshua A. Fogel, published by Columbia University Press in 2019), and Xu 2018 Rethinking China's Rise: A Liberal Critique edited by David Ownby and featuring eight essays written by Xu Jilin and translated by Ownby (published by Cambridge University Press in 2018). Interested readers may also find the website 'Reading the China Dream' (https://www.readingthechinadream.com/about.html) a useful resource. The website, which is run by David Ownby, Timothy Cheek, and Joshua Fogel, with Xu Jilin and a number of others as project collaborators, features many translated articles by Xu Jilin as well as by other Chinese writers.

${ }^{53}$ See, for example, Xu 2007, Jiang 2007, Lv 2007, Zhou 2008, Callahan 2008, and Zhu 2010.

${ }^{54}$ See, for example, Zhao and $\mathrm{Li}$ 2015, Zhao et al. 2016, Zhao 2018, and Zhao et al. 2018.

${ }^{55}$ Zhao 2007, 34.
} 
'the state of ungoverned' (luan) - as the highest virtue and primary principle of 'Chinese' political philosophy. ${ }^{56}$

Unlike Zhao, Xu seeks to reinterpret Tianxia-ism as a kind of Chinese cosmopolitanism operating without any ethnocentric connotation or inclination. In particular, Xu defines his vision as a decentralized and de-hierarchical world built on 'universal civilization' (pushi wenming) rather than on any particular culture. ${ }^{57}$ Xu's insistence to oppose ethnocentrism and particularism stands in contrast to the insignificance of this point in Zhao's writings, and is rooted in Xu's broader intellectual project. Widely regarded as a Liberal, Xu has spent much of his energy over the past three decades in debating with his ideological rivals in China, notably the New Left and the New Confucian. ${ }^{58}$ A key concern for him is the rising nationalism and exceptionalism among contemporary intellectuals. ${ }^{59}$ Calling Chinese nationalism 'a huge yet empty symbol' ${ }^{60}$ he resolutely opposes anti-Westernism while calling for an open mind toward liberty, democracy, and rule of law. As a strategy of debate, $\mathrm{Xu}$ often bases his argument on the same discursive resources of his opponents while subverting their meanings in his favor. For example, in 'Republican Patriotism and Cultural Nationalism,, ${ }^{61} \mathrm{Xu}$ explored how intellectuals of the Republican China have attempted to construct a modern Chinese national identity based on liberal theories. In doing so, Xu both disrupts the statist narrative of Chinese nationalism and gives legitimacy to the discourse of liberalism as an integral part of modern China's struggle with nation- and state-building.

Both his intellectual concern and argumentative strategy are present in Xu's elaboration of New Tianxia-ism. In it, Xu attempts to present a Chinese national identity characterized by open-mindedness, tolerance of diversity, and a will to learn from others. ${ }^{62}$ To frustrate the use of Chinese traditions for nationalist and statist ends, he reappropriates the same intellectual resource to argue against the valorization of any particular national or societal culture as his opponents would have it. ${ }^{63}$ Yet, $\mathrm{Xu}$ is not unaware of the implication of the concept of Tianxia in the discussion of IR. Although affirming the cosmopolitan aspect of Tianxia-ism, he goes to great length to clarify his proposal as not a pretext for reestablishing a Chinese empire, but a call for a 'decentralized and de-hierarchical' international order based on the principle of 'universal civilization'. ${ }^{64}$ Elsewhere, although admitting the importance of a 'cultural self-awakening' in today's China, he warns that 'if cultural self-awakening is meant to construct a particular culture in opposition to the world mainstream civilization, we are better off without such an awakening. ${ }^{65}$

Therefore, different than the proposal by Zhao Tingyang, Xu Jilin's New Tianxia-ism bears the mark of a writer deeply critical of the indigenous scholars'

\footnotetext{
${ }^{56}$ Zhao 2010, 34 .

${ }^{57} \mathrm{Xu} 2015$.

${ }^{58}$ For a brief discussion of $\mathrm{Xu}$ and contemporary public intellectuals in PRC, see Cheek 2006.

${ }^{59}$ Ownby 2018.

${ }^{60} \mathrm{Xu} 2005$.

${ }^{61} \mathrm{Xu} 2006$.

${ }^{62}$ Huang et al. 2012.

${ }^{63}$ Ownby 2018, xxii.

${ }^{64} \mathrm{Xu} 2015$.

${ }^{65} \mathrm{Xu} 2012 \mathrm{~b}, 21$.
} 
tendency to promote one version ethnocentrism (e.g. Sinocentrism) over another (e.g. Eurocentrism). In fact, New Tianxia-ism puts Xu in a minority position within the Tianxia Theories community, where many if not most exhibit an ambivalent attitude toward the idea of a potential Sinocentric order. ${ }^{66}$ As such, we should treat Xu's thesis not as just another formulation of Tianxia-ism in the Chinese IR discourse, but the active attempt of contemporary China's liberal intellectuals to locate a position from where they could communicate their critical understanding of China with a global audience. For this very reason, Xu's New Tianxia-ism is an ideal candidate for a critical investigation into the resilience of Tianxia Theories.

\section{The case for New Tianxia-ism}

$\mathrm{Xu}$ Jilin used the term 'New Tianxia-ism' (xin tianxia zhuyi) to describe his brand of Tianxia Theory for the first time in his 2012 essay, 'Tianxia-ism/ Civilized-Barbarian Distinction and Their Modern Mutation'. Unlike Zhao Tingyang, to this day $\mathrm{Xu}$ has not produced a book-length elaboration for his theory. Instead, he has discussed the subject on various occasions from 2012 to 2016. My analysis of New Tianxia-ism, therefore, is based on a collection of Xu's publications, interviews, as well as speeches over the years. ${ }^{67}$

Xu's New Tianxia-ism is defined against the notion of Traditional Tianxia-ism. Similar with the afore-mentioned popular definition, Traditional Tianxia-ism refers to the ideal political order of ancient China which entails simultaneously a universal normative order based on Confucianism and an all-encompassing geopolitical order dominated by Chinese civilization. Because of these features, argues $\mathrm{Xu}$, Traditional Tianxia-ism is both cosmopolitan and hierarchical in its spirit. However, since a hierarchy is no longer suitable in the modern era, Xu proposes New Tianxia-ism as the modern adaptation of this philosophy. Xu believes that a 'New' Tianxia-ism that preserves the cosmopolitan outlook of its traditional predecessor - minus the notion of order through hierarchy - would best suit both today's China and the world. In short, New Tianxia-ism represents a 'moderate cosmopolitanism' (wenhe de shijie zhuyi) that cherishes mankind's universal civilization. ${ }^{68}$

For what problems do we urgently need New Tianxia-ism today? And what makes $\mathrm{Xu}$ believe that New Tianxia-ism would be the best solution for those problems? In Xu's writings, we can identify two different responses. One formulation justifies the need for New Tianxia-ism by appealing to a reader's utilitarian reasoning, whereas the other one seeks to persuade the readers by invoking their primordial sentiment. For the sake of simplicity, I label the first formulation the 'universalist argument' of New Tianxia-ism, and the second 'nativist argument'. Below I summarize and discuss the content of each argument, before presenting my criticisms.

\footnotetext{
${ }^{66}$ See, for example, Sheng 1996, Zhao 2005, Guo 2013, and Qiao 2014.

${ }^{67}$ See Xu 2012b, 2012c, Huang et al. 2012, Xu 2013b, 2015, Davies 2015, Xu et al. 2015, and Xu 2016. Several key essays are available in English in David Ownby's (ed) book Rethinking China's Rise: A Liberal Critique, thanks to his translation. The most important one is Chapter 6 'The New Tianxia: Rebuilding China's Internal and External Order' (pp. 127-54) whose original Chinese version appears in my bibliography under the entry: Xu 2015.

${ }^{68} \mathrm{Xu} 2012 \mathrm{c}$.
} 


\section{Universalist argument: Tianxia-ism as a pacifying device for world politics}

The universalist argument begins with identifying the most pressing problem of today's world as the destructive tendency of nationalism. Xu argues that because nationalism is a form of group identification that binds the idea of ethnicity or race with other commonalities such as language and culture together, it necessarily creates an antagonistic relationship between the categories of 'Self' and 'Other'. This leads to an ever-growing sense of out-group bias, even outright hostility. Although $\mathrm{Xu}$ credits nationalism for helping China and other Third World nations in their struggle against colonialism and imperialism, he faults it for inciting hatred and mobilizing violence on a massive scale. Xu believes that as long as nationalism predominates our thinking, violence, and conflicts will persist in this world. ${ }^{69}$

Specifically, Xu lists several challenges that China immediately faces, which he believes attributable to the primacy of nationalism as the operating principle of today's politics. These include both internal ethnic tensions and external inter-state antagonism in the nearby region. According to $\mathrm{Xu}$, rising ethno-nationalism is directly responsible for ethno-religious conflict, terrorism, and separatism in places such as Tibet and Xinjiang. These disrupts and destabilizes China's internal order (neibu zhixu). At the same time, heightening nationalist sentiments among Asian countries, argues $\mathrm{Xu}$, are the root cause of diplomatic tensions and territorial disputes between China and its neighbors, which increase the likelihood of regional warfare and endanger China's external order (waibu zhixu). For Xu, the only way to prevent both situations from aggravating further is to adopt a different way of thinking that counters the Westphalian 'nation-state consciousness' (minzu guojia yishi)..$^{70}$

Xu's solution is New Tianxia-ism. Echoing Zhao Tingyang's Tianxia System, Xu defines the normative content of New Tianxia-ism as the pursuit of an orderly and peaceful world. But different than Zhao, whose solution is an all-encompassing world institution modeled on traditional patriarchal family, New Tianxia-ism calls instead for a dialog among different cultures with the aim of locating the 'overlapping consensus' (chongdie gongshi) and building 'universal civilization' (pushi wenming), which are based on his reading of Huntington's Clash of Civilization and refer to the idea of locating commonalities among different cultures in a multicivilizational world. New Tianxia-ism articulates a worldview without center or hierarchy, but beyond the horizon of nation-states. ${ }^{71} \mathrm{He}$ explicitly excludes any attempt to centralize authority or to privilege particular culture. Instead, he argues for the importance of appreciating diversity and celebrating pluralism. The basis of this new world order is 'universal civilization', which poses a question that transcends the 'narrow' perspective of nation-states: 'what is good for all mankind?.' ${ }^{72}$ In short, $\mathrm{Xu}$ believes that the 'evil' of nationalism necessitates a radical

\footnotetext{
${ }^{69} \mathrm{Xu} 2015$.

${ }^{70} \mathrm{Xu} 2015$.

${ }^{71}$ Here and elsewhere in this paper, I use the term 'worldview' in the popular sense of the word, which corresponds to the Chinese term shijieguan, which refers to a totalizing image about the 'world', including the basic attributes of its constitutive components, how different things related to one another, and the mechanisms driving the inner dynamics and so on.

${ }^{72} \mathrm{Xu} 2015$.
} 
re-orientation in terms of how we think about ourselves and the world. This alternative way of thinking is New Tianxia-ism.

\section{Nativist argument: Tianxia-ism as the key to China's selfhood}

The nativist argument of New Tianxia-ism assumes a fundamental difference between the 'Chinese Civilization' and 'Western Civilization'. This difference can be further specified as 'Tianxia-ist East vs. Nationalist West'. Accordingly, China has maintained a consistently Tianxia-ist worldview throughout its history, characterized by being adaptive to political change and accommodating toward diversity. This worldview constitutes both the essence of and the reason for the allegedly openminded, peaceful, and harmonious Chinese civilization. Today's China has lost this character due to its encounter with the West in the late $19^{\text {th }}$ century. Consequently, China needs to bring the Tianxia ideal back. ${ }^{73}$

To demonstrate, Xu employs a 'continuity-rupture' narrative which divides the history of China into only two phases, each of which is defined by the specific worldview of the ruling regimes. The resulting periodization thus includes a premodern 'continuity' and a modern 'rupture'. Pre-modern 'continuity' covers the period from the beginning of Chinese civilization to the point of the First Opium War (1839-1842 CE) in the late Qing Dynasty. This period is understood as an uninterrupted operation of Tianxia-ism, where China enjoyed peace and harmony. The modern 'rupture' begins with the Opium War and persists until the present day, a phase understood as the defeat of Tianxia-ism by nationalism, where China was forced to give up its tradition and become 'just like the others'. This phase also contains the possibility for a different future, should China decide to revive Tianxia-ism through a modern adaptation. ${ }^{74}$

Although Traditional Tianxia-ism gives pre-modern China its unique character as a peaceful and harmonious civilization, it was not perfect. $\mathrm{Xu}$ points out that Traditional Tianxia-ism contains the notion of 'Civilized-Barbarian Distinction' (yixia zhibian), whereby non-Chinese ( $y i)$ are set apart from Chinese (xia) and treated as barbarians due to the former's nonconformity with Confucianism. Xu argues that this view is outdated but maintains that it nonetheless provides people in ancient China with a universal philosophy (i.e. non-Han people such as Manchu and Mongols could also become legitimate rulers of China) and cosmopolitan tolerance (i.e. people who reject Confucianism such as Tibetans and Muslims can coexist peacefully with Han Chinese). As such, Traditional Tianxia-ism represents a superior worldview than the nationalist one embodied by the West. More importantly, Xu argues that the Tianxia worldview was so fundamental to the identity of China that its loss led to a traumatic rift between today's China and its past. The consequence of this 'rupture' is that China finds itself in a serious identity crisis ever since. $^{75}$

In sum, Xu tells us that the Chinese civilization has been superior to the West because of its Tianxia-ism. This deciding factor as well as core identity of China

\footnotetext{
${ }^{73} \mathrm{Xu} 2012 \mathrm{c}$.

${ }^{74} \mathrm{Xu} 2012 \mathrm{c}$.

${ }^{75} \mathrm{Xu} 2012 \mathrm{c}$.
} 
was lost during its encounter with the West. Thus, China must bring it back. But bringing it back would not only benefit China, but also the world at large as well. In other words, because Tianxia-ism worked once in one place, it would work again today everywhere. All that we need is to update it by removing the notion of Confucian-superiority and hierarchy. Then the product, that is, New Tianxia-ism, would be the perfect solution to cure all the ills of the world (for which the West is alone responsible).

\section{The internal tensions of New Tianxia-ism}

In this section, I assess the strength and weakness of New Tianxia-ism on its own terms and against its own objectives. As I shall show, the tension between the two arguments underlie a fundamental problem of Xu's thesis.

\section{Universalist and nativist argument: criticisms of logic and evidence}

The universalist argument of New Tianxia-ism builds on the assumption that nationalism is the root cause of all the conflicts and wars in today's world. One must directly attack this root if one wants to resolve them once and for all. Although $\mathrm{Xu}$ might be right about the destructive potential of nationalism, there is little indication in his writings that he is aware of the extant literature on this topic. Peace and security of the modern international system have been the central concern of both scholars and practitioners of IR. ${ }^{76}$ One can argue that the entire array of post-war international institutions was created to address those problems, by doing what New Tianxia-ism prescribes, that is, promoting dialog and finding consensus among nations. In other words, there is not much new in the substance of Xu's proposal. Xu's more abstract point, that is, how we conceive the world shapes how we behave and how society operates, might resemble Wendt's early argument, particularly his point about the co-constitution of the sovereign state and international system. ${ }^{77}$ But even if we accept Xu's reductionist claim which faults nationalism for all the problems, it still doesn't follow that a non-nationalistic way of thinking would necessarily be the solution, if practical at all. Without much theoretical or practical novelty, Xu's theory sounds like just another popular cosmopolitan proposal about seeking common value over narrow national agendas - with a Tianxia hat. ${ }^{78}$

The nativist argument, on the other hand, draws upon a narrative of identityloss due to the interruption of a foreign force. It argues that because China maintained its peaceful and harmonious existence until the Western interruption, it needs to retrieve this tradition so to resume the 'good old days'. Additionally, because this interruption also destroyed China's self-confidence, reviving Tianxia is the key to the reconstitution of it. Here, $\mathrm{Xu}$ is following the footsteps of many contemporary writers in portraying China as a civilizational entity possessing the

\footnotetext{
${ }^{76}$ See, for example, Keohane 1984, Katzenstein 1996, Wendt 1999, Waltz 2001, Mearsheimer 2001, and Keohane and Nye 2012.

${ }^{77}$ Wendt 1992.

${ }^{78}$ See, for example, Annan 2001.
} 
timeless essence of peace-loving and open-mindedness across the millennium. ${ }^{79}$ However, even a cursory reading of the literature would suggest that deception, competition, power politics, and violence were the norm rather than the exceptions in China's history. ${ }^{80}$ Tibet, for example, had been a security threat to its eastern neighbors for centuries and became a formidable contender for regional dominance against the Tang Dynasty, whose emperor was compelled to agree to a marriage alliance with the Tibetan king. This episode is often depicted by Chinese writers as an example of Chinese benignity toward foreign countries as guided by the spirit of Tianxia, despite records showing that the Tang court only agreed to such a solution after suffering major military defeats at the former's hand. ${ }^{81}$ Similarly, Mongol and Manchu established their respective 'Chinese' empires only after decades of brutal warfare against those who refused to conform, including the Han-led Song and Ming Dynasties. One would have to radically alter the meaning of 'peace' and 'harmony' to explain why the Tianxia philosophy did not prevent the violence and human suffering involved in those dynastical transitions as it is advertised to be capable of. ${ }^{82}$

Thus, it is fair to say that the inaccuracy and sometimes arbitrariness of this representation of history should have long exhausted its currency within the scholarly discourse. Yet, its persistent vitality suggests that there is more to it than its ability to stand against academic scrutiny. For many writers, this narrative legitimizes the idea that Tianxia-ism is not only a Chinese tradition, but the Chinese tradition. ${ }^{83}$ From time to time, $\mathrm{Xu}$ also seems to equate Tianxia-ism with both the governing philosophy of the imperial Chinese court and the actual outcome of its governance. This betrays a circular reasoning that could further undermine his argument. Even if we concede that the point of Tianxia-ism is not to explain in a positivist fashion but to offer an interpretive framework for understanding China's diplomatic culture, ${ }^{84}$ detachment from a solid empirical basis nonetheless would weaken its persuasive power. Last but not least, the nativist argument fails to justify its relevance in front of a global audience. The argument simply does not answer the question: if reviving Tianxia-ism is about saving China from its own identity crisis, why should anyone else care about it?

To summarize, the universalist argument proposes to use New Tianxia-ism to address the problem caused by nationalism yet offers no convincing evidence to support its effectiveness. It also does not answer how the concrete practices suggested by New Tianxia-ism would be different than the existing political and institutional arrangements. On the other hand, the nativist argument, which proposes to revive New Tianxia-ism so to retrieve China's tradition, is based on an inaccurate and sometimes arbitrary reading of the history. Moreover, it fails to establish its relevance with those unconcerned about China's identity crisis. Neither can be con-

\footnotetext{
${ }^{79}$ See, for example, He 2006, Qu 2011, Kang 2008, and Wang and Su 2015.

${ }^{80}$ See, for example, Johnston 1998, Hui 2005, Hu 2006, Wang 2011, Callahan 2012, and Zhang 2015.

${ }^{81}$ Pan 1992, 1997, Norbu 2001.

${ }^{82}$ Barfield 1989.

${ }^{83}$ See, for example, Sheng 1996, Zhao 2003, Qu 2011, Xu 2012c, and Guo 2013.

${ }^{84}$ Hollis and Smith 1990.
} 
sidered sound on its own. Combining the two in one thesis, however, makes it only more confusing and self-defeating.

\section{New Tianxia-ism: a Chinese proposal to reorder the world}

Because the only real-world application of Tianxia-ism that ever-existed is to be found in ancient China, the nativist argument in effect serves as the empirical basis for the universalist argument. In return, because the nativist argument focuses almost exclusively on the issue of China's identity crisis, the universalist argument helps to establish its theoretical relevance with a global audience. The two arguments are thus complementary to one another and integral to Xu's theory as a pair. The logical link between the two is their shared assumption that Tianxia-ism represents an entirely different - even opposite - logic of world politics to nationalism, which $\mathrm{Xu}$ deems to be the ultimate culprit behind both modern China's identity crisis and persisting conflicts around the world. This formulation of a 'good Tianxia-ism' vs. a 'bad nationalism' constitutes the conceptual basis for both arguments, giving one the impression of consistency between them.

However, this formulation directly undermines Xu's goal to build a non-ethnocentric theory of international politics. To support the claim of Tianxia-ism over nationalism, Xu emphasizes - throughout his writings - a consistent dichotomy. This dichotomy starts from the idea that collective identification has only two possibilities. If it is based on culture, then it is necessarily flexible, fluid, tolerant, and promotes friendship and peace. If it is based on race or ethnicity, then it is necessarily rigid, static, narrow-minded, and promotes prejudice and mistrust. From there, $\mathrm{Xu}$ derives two ideal-types of totalizing worldviews: the culture-based Tianxia-ism and the race/ethnicity-based nationalism. The former embraces tolerance, mutual learning, and common value whereas the latter promotes parochialism, xenophobia, and selfishness.

If the dichotomy stops here, its problem remains largely conceptual. That is, we may still debate whether such categorization has any empirical support or offers analytical leverage. One can suggest, for example, that its reliance on the concept of race as distinct from culture suggests a definition similar to the ones used by racial scientists, yet which has been long abandoned by the social scientific community. ${ }^{85}$ But in New Tianxia-ism, this conceptual dichotomy is directly mapped onto Xu's comparative cultural argument of China and the West, as he quite explicitly articulated in his 'continuity-rupture' narrative of Chinese history. Thus, the 'Chinese civilization' becomes synonymous with Tianxia-ism, and the 'Western Civilization' with nationalism. As a result, the conceptual foundation of New Tianxia-ism becomes the antagonistic pair of two distinct cultural entities locked in a static ethical hierarchy: Chinese Tianxia-ism vs./over Western nationalism. In this moment, an indigenous proposal of IR theorizing, ironically, becomes a rehearsal of the essentialization and stereotyping of the 'Orient', which is a signature of the colonialist scholarship and ironically, the very target that Tianxia Theories and other Chinese indigenous IR theories seek to challenge and rectify.

\footnotetext{
${ }^{85}$ Dikötter 1998.
} 
Furthermore, since New Tianxia-ism is presented as the alternative to nationalism, Xu's proposal can be interpreted as a call for replacing the norms and rules of the West with those of China. It is true that $\mathrm{Xu}$ explicitly rejected imposing Tianxia-ism onto others. He also defined the essence of New Tianxia-ism as seeking common value among different cultures and building a global community based on the 'overlapping consensus'. Nonetheless, since Tianxia-ism was derived from the Chinese experience alone, it would presumably be seen as a 'foreign culture' to those outside China or unconnected with the Sinophone world. How, then, would one know a priori whether other people will accept it at all? This is particularly puzzling when one considers his repeated emphasis on the gap between East and West. Xu's optimism in his theory's universal appeal seems to run contrary to his conviction in the distinctiveness of each culture and the difficulty for cultural and social change. If people in China had suffered a traumatic identity crisis when they were forced to abandon their culture - Tianxia-ism - in early $20^{\text {th }}$ century, why would it be advisable for anyone else - especially the categorically different 'West' - to abandon their own just so they can adopt a Chinese one? What would Xu's New Tianxia-ism advise if someone refuses to adopt Tianxia-ism and wants to stay in their own way by using the same nativist argument as Xu's? There is little hint in Xu's writing that he has considered such a possibility. Despite Xu's repeated claims that he seeks a non-ethnocentric theory, his insistence on the East-West dichotomy and the universal applicability of New Tianxia-ism makes his argument more like a proposal to replace the existing/Western world order with a Chinese one.

\section{The Sinocentric subject and the paradox of Tianxia-ism}

As discussed earlier, there are good reasons to believe that $\mathrm{Xu}$ was genuine when he said he sought a decentralized, de-hierarchical, and non-ethnocentric world order. 'Anyone who wishes to return to a Sino-centric hierarchical Tianxia order', writes $\mathrm{Xu}$ in the very article where he proposes New Tianxia-ism, is not only making a reactionary movement against history, but also doing a one-party's wishful thinking, ${ }^{86}$ Moreover, we may also sympathize with his New Tianxia-ism as yet another case of 'reappropriating parts of China's past for the liberal cause in innovative ways' ${ }^{87}$ However, the preceding analysis shows that the logic of New Tianxia-ism not only reveals an urge to offer a Chinese solution to the world whose empirical records ultimately relies on a glorified imperial Chinese history, but also reinforces a static conceptual dichotomy between the East and West that contradicts the objective to break boundaries and seek commonality, not to mention putting China at the superior position in an implicit civilizational hierarchy. How could Xu's critique of nationalism and ethnocentrism coexist with his proposal for universalizing a Chinese tradition onto the entire world?

Among writers of Tianxia Theories, $\mathrm{Xu}$ Jilin is not alone in setting himself in such a paradox. Sheng Hong, a former economist at the Chinese Academy of Social Sciences (CASS) and former executive director of the now-disbanded

\footnotetext{
${ }^{86} \mathrm{Xu} 2015$.

${ }^{87}$ Ownby 2018, xxvii.
} 
Beijing-based think tank - Unirule Institute of Economics - had articulated a very similar idea in his article 'From Nationalism to Tianxia-ism'. ${ }^{88}$ Sheng believes that the first unification of China under the Qin Dynasty led to the birth of Tianxia-ism, which transformed China from a country into a 'world'. As a result, nationalism had no place in the consciousness of Chinese, as there was no need for individuals from a world community to have such a 'narrow' idea. Although China had to 'adopt nationalism' to fight off imperialism and colonialism, the world as a whole would ultimately suffer from it, because 'ii]n today's world where nuclear weapons proliferate, nationalism, especially the type that emphasizes the priority of national interests [...] is more dangerous than ever'. ${ }^{89}$ Sheng briefly considers the European integration as one possible solution to overcome nationalism, but quickly dismissed it, citing that Europe is too 'homogenous' to set a model for 'peaceful integration of different cultures'. On the other hand, since 'China is the only civilization in human history that ended a period of warring-states and established a Tianxia culture, its cultural tradition could serve as the source for us to rebuild Tianxia culture today'..$^{0}$ That China worked to develop the country and strengthen the military, claims Sheng, was not only 'to wash away the humiliation that it suffered for more than a hundred years, but to fight for a chance to spread Tianxia-ism to the world.' ${ }^{91}$

Similarly, Guo Yi, a former research associate at CASS's institute of philosophy and a professor of philosophy at Seoul National University, argued that only China would be able to unify the world with its 'rich historical experience' and 'long lasting "world-spirit". ${ }^{92}$ Guo argues that China was never a nation-state, but a 'multinational society unified under Tianxia-ism' instead. He points to the Confucian philosophy as the source for Tianxia-ism, arguing that the former contains such notions as treating everyone as family, pursuing a universal value, winning over enemies using virtue, and accommodating differences. ${ }^{93}$ On the other hand, Western countries cannot escape from the 'narrow-mindedness of nationalism', are predisposed to force their will and their unitary 'Western civilization' upon the entire world, and are doomed to clash with others. Therefore, 'Western national value' (xifang minzu jiazhi), for which Guo cites Fukuyama's 'End-of-History' and Huntington's 'Clash-of-Civilization' as examples, cannot tackle the task of reestablishing world order. Instead, only the Confucian Tianxia-ism represents the universal value in the true sense of the word. Guo envisions that the world population would eventually form a 'unified global nation' through assimilation under the guidance of Tianxia-ism, just like what happened in Chinese history. ${ }^{94}$

Unlike Sheng and Guo, Xu has explicitly professed his criticism against ethnocentrism. In fact, Xu once criticized Sheng's anti-Western stance in his critiques of contemporary Chinese nationalism. ${ }^{95}$ Nonetheless, they all set themselves in a

\footnotetext{
${ }^{88}$ Sheng 1996.

${ }^{89}$ Sheng 1996, 18.

${ }^{90}$ Sheng 1996, 19.

${ }^{91}$ Ibid.

${ }^{92}$ Guo 2013.

${ }^{93}$ Guo 2013, 32.

${ }^{94}$ Guo 2013, 33.

${ }^{95} \mathrm{Xu} 2005$.
} 
paradox by critiquing nationalism and 'Western hegemony' and advocating the universalization of Tianxia-ism and 'Chinese experience' as an alternative at the same time. How could writers of Tianxia Theories perceive their proposal as logically consistent and coherent? As discussed at the beginning of this essay, existing accounts of Tianxia Theories tell us little about how one reconciles the seemingly evident contradictions in their logics. To understand its resilience, we need to examine the conditions that enable the articulation of the very idea of Tianxia. In other words, the more important question is: how is it possible for liberalminded intellectuals such as $\mathrm{Xu}$ Jilin to both reject ethnocentrism and advocate New Tianxia-ism? Asking such a question means to examine the conditions under which it becomes conceivable to think along the logics of Tianxia-ism. Specifically, it requires us to problematize the construction of particular subjectposition that makes the kind of argumentation in Tianxia Theories logical and possible in the first place. ${ }^{96}$ Below I tackle two interrelated questions so to reveal and problematize the subject-position that New Tianxia-ism relies on: (1) how is the particular subject-position constructed so as to make possible the formulation of New Tianxia-ism and potentially other Tianxia Theories? and (2) how does the construction of this particular subject-position render New Tianxia-ism unlikely to offer a truly non-ethnocentric theory of international politics, despite its author's well-intentioned efforts?

\section{The Sinocentric subject}

As the preceding analysis has shown, although New Tianxia-ism speaks of a decentralized and de-hierarchical world that resembles the cosmopolitan vision of some liberal IR theories, Xu's vision is ultimately defined according to the notion of Tianxia. This vision is articulated through a very specific set of discursive practices which we can observe consistently throughout his writings. The following passage, taken from his 2015 piece 'New Tianxia-ism: Rebuilding China's Internal and External Order', offers a good example:

The reason that the Chinese civilization did not decline over the course of five thousand years is precisely because it was not closed and narrow. Instead, it benefitted from its openness and inclusiveness, and never stopped transforming outside civilizations into its own traditions. Employing the universal perspective of Tianxia, China was concerned only with the question of the character of these values. It did not ask questions about 'mine' or 'yours' in the racial sense, but absorbed everything that was 'good', connecting 'you' and 'me' in an integrated whole which became 'our' civilization. However, today's extreme nationalists see China and the West as absolute, natural enemies. They use absolute distinctions of race and ethnicity to resist all foreign civilizations. Even in the academic world there is a popular 'theory of the original sin of Western learning,' according to which anything created by Westerners must be rejected out of hand. [...] This kind of 'politically correct' nationalism seems like it is extolling Chinese civilization, but in fact it is doing

\footnotetext{
${ }^{96}$ Epstein 2011.
} 
just the opposite: it takes the universality of Chinese civilization and debases it into nothing but the particular culture of one nation and one people. [...] China is a cosmopolitan power, a global nation that bears Hegel's 'World Spirit'. It ought to take responsibility for the entire world and for the 'World Spirit' that it has inherited. This 'World Spirit' is New Tianxia-ism that will emerge in the form of universal values. ${ }^{97}$

As one can see from the above excerpt, China is understood by $\mathrm{Xu}$ as a timeless entity whose history revolves around a fixed, single essence throughout the history. None of the conflicts, divisions, and dynastical changes could disturb this essence. Instead, they are simply subsumed under it. The content of this essence is understood as the unwavering pursuit of the so-called 'universal civilization'. At the same time, this quality sets China apart from others, as China is an entity of superior status ('a civilization') whereas other nations operate on a comparatively lower level ('a particular culture'). Such a unique quality not only makes China different than others, but in effect better. Looking more broadly, the world itself is implied to be structured primarily by cultural differences, which not only override any other forms of divisions but also constitute the most fundamental forms of politics. Thus, the greatest problem in the world is when people fixate on cultural differences and seek to privilege some cultures over others. Since only China is operating as a civilization - thus above the level of a particular culture - it could and should (given its responsibility as the bearer of the 'World Spirit') guide the world toward a lasting peaceful and harmonious order by reorganizing the world based on the kind of universal civilization inspired by its own history, that is, New Tianxia-ism.

In sum, the very idea of Tianxia as the ideal political-ethical order presupposes a singular, timeless China transcending history and watching over a world that is divided by culture and ready to be saved by China, which stands as the only authentic universal civilization. This premise invites whoever speaks on behalf of Tianxia to assume a particular subject-position that sees China as the Sovereign Subject with full agency in a world both waiting for - one might also say, wanting - her benign intervention. We know from the preceding analysis that such a construction is predicated on a narrative of 'continuity-rupture'. Thus, to speak of and for a China that has recovered from its victimhood due to the 'rupture' and is ready to help the world with the wisdom retrieved from its historical 'continuity' is doubly empowering, because it not only makes China the benign savior and the civilizing agent of the world but also establishes the unquestionable moral quality of its actions. The invocation of the past victimhood of the same Sovereign Subject simultaneously implies that it would be impossible for China to enact the same evil.

I call this subject-position of New Tianxia-ism the 'Sinocentric Subject'. Its central premise is the notion of a singular, fixed 'China' as a peaceful civilization throughout the history. Beginning from the Republican period (1912-1949 CE), political elites and intellectuals in China have attempted to construct a myth of a

\footnotetext{
${ }^{97}$ The original quote is in Chinese. The English translation included in the present paper was adapted from David Ownby's translation, which appears in his 2018 book Rethinking China's Rise: A Liberal Critique (Cambridge University Press), 131-32. The book includes eight Xu's essays translated by Ownby.
} 
primordial Chinese nation-state that naturalizes 'the imperial distinction between a civilized Chinese center and a backward, barbarian periphery'. ${ }^{98}$ After 1949, the PRC government has also been rewriting the official historiography on Han and non-Han relations, trivializing inter-group conflicts and tensions while emphasizing the 'Chinese-ness' of the historically non-Han people and non-Han ruling regimes. ${ }^{99}$ In today's PRC, this Han-centered narrative of history forms the default subject-position that the state carefully crafts and ardently propagates through an elaborated system of propaganda and censorship. ${ }^{100}$ Passed on to the general public through schools and mass media, this narrative provides a conceptual basis for an average Chinese person to imagine a timeless multiethnic China where Han and non-Han people have always coexisted in a harmonious and peaceful relationship and have always belonged to the same undivided - and undividable - Chinese nation (zhonghua minzu). In doing so, such a narrative provides people the basic coordinates which enable and encourage one to perceive social reality from the same subject-position and reach similar conclusions about what 'China' is and how 'China' should act vis-à-vis the rest of the world. As the example of Xu Jilin and his fellow Tianxia theorists shows, this is a position to which even those critical of contemporary Chinese nationalism are vulnerable.

By assuming this position, they are able to perceive the logic of Tianxia-ism as natural and unproblematic. More specifically, a Sinocentric Subject is able to perceive the universalist argument and nativist argument as non-conflictual and integral to a single unified thesis. As previously discussed, although the universalist argument proposes to save a world threatened by nationalism with Tianxia-ism, the nativist argument proposes to save a China traumatized by nationalism with Tianxia-ism. The tension between the two should alert an average reader of the ethnocentric undertone behind its explicit claim to the contrary. But a Sinocentric Subject is not only able but also encouraged to see the two as one and same, because from this subject-position's point of view, saving the world is equivalent to and fundamentally about saving China. Once the equivalency of China and the world is naturalized, then the logic of Tianxia-ism flows.

Even Xu's repeated and explicit rejection of ethnocentrism, the very signature of New Tianxia-ism, plays right into the Sinocentric logic. How so? Only an authentic civilizational center as the 'West' has the potential to do evil to the world with its own brand of ethnocentrism. Thus, being a civilizational center is the logical prerequisite for the disavowal. Those who were not considered in the narrative of Tianxia-ism for their potential of doing evil with ethnocentrism (e.g. Korea, Tibet, or Vietnam), by implication, are not even qualified to renounce it. Therefore, by denouncing China's intention to repeat the ethnocentrism of Old Tianxia-ism, the logic of New Tianxia-ism already betrays the Sinocentric subject as the implicit speaker behind the text: in a world threatened by the West and its ethnocentric civilization (i.e. nationalism), only China and its universal civilization (i.e. Tianxia-ism) could save the day.

\footnotetext{
${ }^{98}$ Leibold 2007, 15.

${ }^{99}$ Baranovitch 2010.

${ }^{100}$ Brady 2013.
} 


\section{The paradox of Tianxia-ism}

What does the Sinocentric Subject mean for New Tianxia-ism? As we know, Xu does not want to create a theory based on any ethnocentric premise, but to overcome it. Thus, it is against this objective that his theory of New Tianxia-ism should be judged. Unfortunately, the Sinocentric Subject on which Xu's theory relies ultimately undermines his objective of articulating an alternative, non-ethnocentric theory of world politics. As Xu himself admits, China as a nation-state only emerged following its modern encounter with the West. The very idea of a singular, fixed essence of China saw its popularity among Chinese writers only following their encounter with modern Western historiography and Sinology in the early $20^{\text {th }}$ century. ${ }^{101}$ This is not to suggest that the idea of China was merely a construct engineered by Western imperialism. Rather, the point is that this imperial encounter ${ }^{102}$ was an indispensable part to the construction of modern Chinese nation/ state. The encounter compelled indigenous elites of various ethnic, religious, and political aspirations across the country to react to what they perceived as an existential crisis to their 'imagined communities', ${ }^{103}$ which resulted in various forms of struggles not only against the West but also against each other. ${ }^{104}$ Consequently, China's nation- and state-building was an extremely violent political project. This means that the very idea of singular, fixed 'China' sits uneasily with those who are oppressed, marginalized, or excluded in this process. Just as the notion of Tianxia was used by official historians to glorify the violence, war, and conquest during China's imperial age, so does it serve as the legitimation strategy for the violence involved in making the modern China today.

Even more problematically, as China reemerges as a global power in the $21^{\text {st }}$ century, there remain persisting problems that point to the 'underbelly' of its nationand state-building process. To name just a few examples: patriarchal family structures and gender inequality remains prevalent, ${ }^{105}$ which is also reflected in the marginal position of feminist scholarship in China's indigenous IR. ${ }^{106}$ Although ethnic minorities saw general improvement in their socioeconomic conditions over the decades since PRC's founding, a number of groups continue to feel threatened as their demands for cultural and political autonomy are perceived as a security threat by the state. ${ }^{107}$ Outside China, territorial disputes and other interstate frictions have increased despite more intense economic, political, and cultural exchanges between China and its neighbors. ${ }^{108}$ If $\mathrm{Xu}$ and his fellow Tianxia theorists intend to offer a genuine alternative discourse that could rectify the parochialism in existing IR, which - as they all agree - has to do with privileging some people's perspective and experience over others, then wouldn't the crucial test for New Tianxia-ism be precisely its ability to recruit those listed above into its political project, that

\footnotetext{
${ }^{101}$ Wang 2003.

${ }^{102}$ Doty 1996.

${ }^{103}$ Anderson 2006.

${ }^{104}$ See, for example, Rhoads 2000, Groot 2004, Lin 2006, Tuttle 2007, and Bulag 2010.

${ }^{105}$ Jeffreys 2006, Zheng 2009.

${ }^{106}$ Blanchard and Lin 2016.

${ }^{107}$ Goldstein 1997, Bovingdon 2010, Kaltman 2014.

${ }^{108}$ Wright 2001, Hayton 2014.
} 
is, those who find themselves on the margin to the project of building a modern Chinese nation/state?

Can those people find their voice in the framework of New Tianxia-ism and its grand narrative of a singular, timeless China rising above history to spread its universal civilization? Specifically, would the women in China whose role was confined within a patriarchal family be willing to stand by this narrative and root for a New Tianxia? Would ethnic minorities whose languages and cultures were once considered inferior and primitive under the Sino-Confucian order be willing to root for a New Tianxia? Would people in Vietnam and the Korean Peninsula whose governments were once considered as vassal states to the Chinese imperial court be willing to root for a New Tianxia? And would people from countries that were never part of the Sino-Confucian order such as India, Pakistan, and Afghanistan be willing to root for a New Tianxia? As Barabantseva acutely observes, the idea of Tianxia 'as a system of governance valuing order, stability, and hierarchy [...] does not account for the tensions, inconsistencies, and struggles that take place in China at multiple levels as an integral part of its interactions with the modern world'. ${ }^{109}$ Spivak points out that the construction of an undivided Sovereign Subject against the colonial power often comes at the expenses of continuing and further oppression of women and other marginal subjects. Critical intellectuals such as Foucault and Deleuze, according to Spivak, are partially responsible by assuming themselves to possess unmediated access to the oppressed and thus entitled to speak of and for the latter as a transparent object. ${ }^{110}$ Indigenous intellectuals in contemporary China should not be exempted from this critique, for they are also vulnerable to the tendency of treating uncritically their own position whereas speaking on behalf of the imaginary collective Self, for example, 'China' or 'the Chinese civilization'. In the case of New Tianxia-ism - and Tianxia Theories in general - the consistent presence of a Sinocentric Subject seems to follow a very similar pattern of anti-colonial intellectuals criticized by Spivak. Ironically, although New Tianxia-ism aims to overcome and replace nationalism, its reliance on an essentialized identity of China as anti-Western and anti-nationalistic - the very core element of the Sinocentric Subject - reproduces the horizon of nationalism even while criticizing its content. In the end, New Tianxia-ism not only fails to meet its objective of offering a cosmopolitan vision, but also perpetuates if not reinforces the very problem that it targets.

\section{Ideology, politics of knowledge in the non-West, and global IR}

The discussion has two main implications for global IR. First of all, if the resilience of Tianxia Theories in Chinese IR is a result of contemporary Chinese intellectuals speaking from the subject-position of the Sinocentric Subject, then it would be important for critics of Tianxia Theories - and scholars of global IR in general to pay due attention to the collective ideological inclinations of their Chinese/ non-Western interlocutors. As Althusser argued, the very 'obviousness' that one could act as a subject 'spontaneously' or 'naturally' is itself an effect of ideology,

\footnotetext{
${ }^{109}$ Barabantseva 2009, 133-34.

${ }^{110}$ Spivak 1988.
} 
which has the ability to impose obviousness as obviousness. ${ }^{111}$ Studying how Chinese scholars naturalize and embrace the Sinocentric Subject in their knowledge production, from this perspective, means to investigate the process of collective subject-position formation within the ideological spectrum of contemporary China. As well documented by scholars of different fields, social science was never free of ideology. ${ }^{112}$ In particular, 'by offering a developed and coherent picture of how Self fits with its environment, ideology introduces a series of clearly articulated and hidden assumptions that may then find their way into social science scholarship.' ${ }^{113}$ However, the intensity of scholarly efforts to examine non-American and non-Western ideological assumptions in non-Western IR have not matched that for American and the Western ones. ${ }^{114}$

In China, political and institutional factors that undermine academic autonomy do exist. Similarly to elsewhere, ${ }^{115}$ Chinese scholars have also been traditionally involved in the political domain. A recent study shows that there might have been a deliberate 're-ideologisation' of social sciences by the Chinese Communist Party in the last decade in the much broader sense of manifesting hegemonic claims for a historiographically bolstered self-assertion of China's national culture. ${ }^{116}$ However, it is easier to forget that scholars are not necessarily ideologically opposing or diverging from the state; neither can they be simply reduced to the passive 'mouthpiece' of the authority. As Buzan observed, ${ }^{117}$ the practice-driven tendency of the Chinese IR scholarship might even become less over time as the community itself becomes more professionalized and academically-driven. If so, then studying the ideological inclinations of the Chinese/non-Western scholars besides the overt and/or covert control of the state will be more relevant to a better understanding of the IR epistemic community in China/non-West and of the ways to further promote the inter-cultural dialogues that global IR pursues.

Second, if the root of ethnocentrism in Tianxia Theories lies in the rigidly selective reading of history from the standpoint of the Sinocentric Subject, then a more effective and constructive critique of Tianxia Theories - and ethnocentrism in other non-Western IR theories - could be practiced by bringing awareness, attention, and reflexivity to the politics of knowledge not only between West and non-West, but also within and among non-Western societies. In other words, we should not only be mindful of those histories that lie outside the 'Eurocentric story about the founding of the modern state, ${ }^{118}$ but also those lie outside the Sinocentric story about the 'reconsolidation' or 'rejuvenation' of China. ${ }^{119}$ As the preceding analysis has shown, a Sinocentric Subject's reading of history not only feeds orientalist assumptions of the West about China ${ }^{120}$ and reproduces the 'West

\footnotetext{
${ }^{111}$ Althusser 1994.

${ }^{112}$ Said 1979, Latham 2000, O’Connor 2001, Oren 2003.

${ }^{113}$ Tsygankov and Tsygankov 2010, 666.

${ }^{114}$ Tsygankov and Tsygankov 2010, 679.

${ }^{115}$ See, for example, Tickner 2008 and Makarychev and Morozov 2013.

${ }^{116}$ Holbig 2014, 27.

${ }^{117}$ Buzan 2018.

${ }^{118}$ Tickner 2016, 158.

${ }^{119}$ Wang 2014.

${ }^{120}$ Schneider 2014, 703.
} 
vs. non-West' binary hierarchy that global IR seeks to challenge, ${ }^{121}$ but also perpetuates 'internal orientalism ${ }^{, 122}$ that serves to silence the multiple narratives of history that exist within the contemporary nation-state's borders. Consequently, questioning the power relations behind the writing of history and paying attention to the oppression of multiple voices in intellectual traditions of China are just as important to liberating IR from Eurocentrism as they are to liberating Chinese IR from Sinocentrism.

What do these entail specifically? If global IR is about moving our focus away from the core to the periphery (or non-core), then the discussion about Chinese IR should also make a similar effort to move its obsession away from what they have so far assumed to be the singular, fixed, 'authentic' Chinese civilization to those places, actors, histories, and traditions outside the center, reengage the history of China by taking a 'frontier' perspective, ${ }^{123}$ be reflective of issues of race and ethnicity, ${ }^{124}$ gender, ${ }^{125}$ and politics of knowledge production, ${ }^{126}$ and pay due attention to 'the actual academic practices and individuals who have contributed to the development of the field'.

The Chinese interlocutors of global IR are an important partner in this collective effort. It should be emphasized that Tianxia Theories, while influential, remains but one of the many voices emitting from China, where a vibrant and increasingly professional academic community operates. As mentioned earlier, Tianxia Theories have met with strong criticism for promoting Sinocentrism. A good amount of them came from China. To name just a few examples, $\mathrm{Xu}$ Jianxin argues that Zhao Tingyang employed a false equivalency in his comparison between China and the West when Zhao contrasted the best ideal-typical scenario articulated by Chinese philosophers with the worst actual scenarios in today's world, thereby erroneously exaggerating the differences between the two sides. ${ }^{128}$ Along similar lines, Zhou Fangyin disputes the track record of Tianxia-ism, pointing to the constant tension between the central and regional governments throughout the Chinese history. ${ }^{129}$ Zhu Qiyong, although concedes that there might be benefits to revisit the notion of Tianxia, cautions that one must 'remain keenly aware of the internal contradictions and historical predicament of Tianxia-ism' ${ }^{130}$ Finally, responding to Xu Jilin's quest for 'universal civilization', Bai Yongrui (Baik Youngseo) writes that 'one can only discover the universal elements that make possible the communication between Hong Kong, Macao, Taiwan, as well as various borderland minority areas if one rethinks from the perspective of periphery instead of the center'. ${ }^{13}$ These commentaries show the ability of the intellectual community in today's

\footnotetext{
${ }^{121}$ Owen et al. 2018.

${ }^{122}$ Gladney 1994, Schein 1997.

${ }^{123}$ Liu 2010.

${ }^{124}$ Carrico 2017, Barder 2017, Lu 2017.

${ }^{125}$ Blanchard and Lin 2016.

${ }^{126}$ Noakes 2014, Chu 2015.

${ }^{127}$ Hellmann and Valbjørn 2017, 281.

${ }^{128} \mathrm{Xu} 2007,135-37$.

${ }^{129}$ Zhou 2008, 102-03.

${ }^{130}$ Zhu 2010, 54.

${ }^{131}$ Baik 2016, 85.
} 
China to practice self-critique and reexamine knowledge constitutive to the Chinese nationalist narrative, as well as the space for such an exercise. I hope that the discussion in this paper may contribute to the endeavor of Chinese scholars to critique ethnocentrism and local particularism by bringing greater awareness to the Sinocentric Subject and its implication for Tianxia Theories.

\section{Conclusion}

Within the Chinese academic community today, Tianxia Theories have been particularly vocal in pitching their ideas as not just another overlooked philosophical tradition in the social science discourse, but an alternative foundation for studying world politics. Yet, more often than not these efforts display a lack of self-critique on the politics of knowledge. Rather than taking lessons from the debates in IR - in particular the interventions of postcolonialism, feminism, and critical theory - many indigenous scholars seem more interested in developing theories that privilege a particularistic reading of China, responding to 'Western ethnocentrism by putting forth an ethnocentric paradigm of their own making. ${ }^{132}$

In the spirit of advancing a genuine 'two-way' dialog, this article has attempted to engage Tianxia Theories on an epistemic level to understand its appeal to contemporary Chinese intellectuals. As I have attempted to shown, the case of New Tianxia-ism represents an example of a non-Western response to Eurocentrism in IR through a self-enacted essentialization and indigenous parochialism, despite its author's genuine intention to attack ethnocentrism and local particularism in contemporary Chinese nationalist narrative. I further argue that the problem with New Tianxia-ism does not stand as an isolated phenomenon but is symptomatic of the predicament of many Chinese writers who share an interest in contributing to the global discourse on IR with indigenous perspective and experience. As they base their theory-building on a rigid notion of China as an essentialized, singular, timeless entity, their endeavor not only reinforces the East-West dichotomy but also perpetuates the marginalization of dissenting voices to the Sinocentric narrative both within and outside China.

Based on the discussion, I suggest that for interlocutors of global IR to rectify epistemic ethnocentrism of the global IR project, greater attention should be given to the collective ideological inclination of non-Western epistemic communities as well as the politics of knowledge among non-Western societies. This could be practiced by taking a critical yet sympathetic attitude to engage more substantively the content of Chinese/non-Western contributions, bringing in 'subjugating marginalized perspectives' from places, actors, histories, and traditions outside the conventionally assumed center. Doing so will hopefully help to move the discussion of global IR beyond the 'two-way dialogue' toward a multidirectional and multilevel dialog of greater plurality and reflexivity.

Acknowledgement. The research for this essay was supported by the Konrad Adenauer Foundation (Konrad-Adenauer-Stiftung) and the German Research Foundation (Deutsche Forschungsgemeinschaft, project no. 394229330). An earlier version of this paper was presented at the Doctoral Student

\footnotetext{
${ }^{132}$ Acharya and Buzan 2010, 227.
} 
Colloquium of the German Institute for Global and Area Studies in February 2018. Special thanks goes to L. H. M. Ling for inspiring and encouraging me to undertake this research. I am indebted to Emanuela Garatti, Heike Holbig, Qiang Jin, Medha, Christian Wirth, and the editor and the anonymous reviewers of International Theory for their valuable comments and suggestions. Any remaining errors are my own.

\section{References}

Acharya, Amitav. 2014. "Global International Relations (IR) and Regional Worlds: A New Agenda for International Studies.” International Studies Quarterly 58 (4): 647-59.

Acharya, Amitav. 2016. "Advancing Global IR: Challenges, Contentions, and Contributions." International Studies Review 18 (1): 4-15.

Acharya, Amitav, and Barry Buzan, eds. 2010. Non-Western International Relations Theory: Perspectives On and Beyond Asia. London: Routledge.

Acharya, Amitav, and Barry Buzan. 2017. "Why Is There No Non-Western International Relations Theory? Ten Years On." International Relations of the Asia-Pacific 17 (3): 341-70.

Althusser, Louis. 1994. "Ideology and Ideological State Apparatuses (Notes Towards an Investigation)." In Mapping Ideology, edited by Slavoj Žižek, 100-40. London; New York: Verso.

Anderson, Benedict. 2006. Imagined Communities: Reflections on the Origin and Spread of Nationalism. Revised edition. London, UK; New York, USA: Verso.

Annan, Kofi. 2001. "Nobel Lecture Delivered by Kofi Annan | United Nations Secretary-General." United Nations Secretary-General. December 10. https://www.un.org/sg/en/content/sg/speeches/2001-12-10/ nobel-lecture-delivered-kofi-annan.

Babones, Salvatore. 2017. "Taking China Seriously: Relationality, Tianxia, and the 'Chinese School' of International Relations." Oxford Research Encyclopedia of Politics. Accessed 18 May 2020. https://doi. org/10.1093/acrefore/9780190228637.013.602.

Baik, Youngseo 2016. "Cong hexin xianchang chongsi xinde pubian: pinglun xin tianxia zhuyi [Reconsidering the 'New Universalism' from the Standpoint of Core Locations: A Review of 'New Tianxia-ism]." Open Times, No. 1 (January):82-94.

Barabantseva, Elena. 2009. "Change vs. Order: Shijie Meets Tianxia in China's Interactions with the World." Alternatives: Global, Local, Political 34 (2): 129-55.

Baranovitch, Nimrod. 2010. "Others No More: The Changing Representation of Non-Han Peoples in Chinese History Textbooks, 1951-2003." The Journal of Asian Studies 69 (1): 85-122.

Barder, Alexander D. 2017. "Race and International Relations." International Studies Review 19 (3): 509-16.

Barfield, Thomas J. 1989. The Perilous Frontier: Nomadic Empires and China. Studies in Social Discontinuity. Cambridge; Oxford: Wiley-Blackwell.

Blanchard, Eric M., and Shuang Lin. 2016. "Gender and Non-Western 'Global' IR: Where Are the Women in Chinese International Relations Theory?" International Studies Review 18 (1): 48-61.

Bovingdon, Gardner. 2010. The Uyghurs: Strangers in Their Own Land. New York: Columbia University Press.

Brady, Anne-Marie. 2013. “We Are All Part of the Same Family': China's Ethnic Propaganda." Journal of Current Chinese Affairs 41 (4): 159-81.

Bulag, Uradyn Erden. 2010. Collaborative Nationalism: The Politics of Friendship on China's Mongolian Frontier. Asia/Pacific/Perspectives. Lanham, MD: Rowman \& Littlefield Publishers.

Buzan, Barry. 2018. "How and How Not to Develop IR Theory: Lessons from Core and Periphery." The Chinese Journal of International Politics 11 (4): 391-414.

Callahan, William A. 2008. "Chinese Visions of World Order: Post-Hegemonic or a New Hegemony?" International Studies Review 10 (4): 749-61.

Callahan, William A. 2012. "Sino-Speak: Chinese Exceptionalism and the Politics of History." The Journal of Asian Studies 71 (1): 33-55.

Carrico, Kevin. 2017. The Great Han Race, Nationalism, and Tradition in China Today. Oakland: University of California Press.

Chang, Chishen. 2011. "Tianxia System on a Snail's Horns." Inter-Asia Cultural Studies 12 (1): 28-42.

Cheek, Timonthy. 2006. "Xu Jilin and the Thought Work of China's Public Intellectuals." The China Quarterly 186:401-20. 
Chen, Ching-Chang. 2011. "The Absence of Non-Western IR Theory in Asia Reconsidered." International Relations of the Asia-Pacific 11 (1): 1-23.

Chu, Yiting. 2015. "The Power of Knowledge: A Critical Analysis of the Depiction of Ethnic Minorities in China's Elementary Textbooks." Race Ethnicity and Education 18 (4): 469-87.

Collins, Randall. 1998. The Sociology of Philosophies: A Global Theory of Intellectual Change. Cambridge, Massachusetts: Belknap Press of Harvard University Press.

Collins, Randall. 2000. “The Sociology of Philosophies: A Précis.” Philosophy of the Social Sciences 30 (2): 157-201.

Collins, Randall. 2002. "On the Acrimoniousness of Intellectual Disputes." Common Knowledge 8 (1): 47-70.

Cunningham-Cross, Linsay. 2012. "Using the Past to (Re)Write the Future: Yan Xuetong, Pre-Qin Thought and China's Rise to Power." China Information 26 (2): 219-33.

Cunningham-Cross, Linsay. 2014. "In Search of a Chinese School: Ghostly Encounters with the Parochial/ Global Discipline of International Relations." PhD Thesis, University of Manchester.

Davies, Gloria. 2015. "The Practice of History and China Today | The China Story." August 26. https:// www.thechinastory.org/cot/the-practice-of-history-and-china-today/.

Dikötter, Frank. 1998. "Race Culture: Recent Perspectives on the History of Eugenics." The American Historical Review 103 (2): 467.

Doty, Roxanne Lynn. 1993. "Foreign Policy as Social Construction: A Post-Positivist Analysis of U.S. Counterinsurgency Policy in the Philippines." International Studies Quarterly 37 (3): 297-320.

Doty, Roxanne Lynn. 1996. Imperial Encounters: The Politics of Representation in North-South Relations. Borderlines 5. Minneapolis: University of Minnesota Press.

Epstein, Charlotte. 2011. "Who Speaks? Discourse, the Subject and the Study of Identity in International Politics." European Journal of International Relations 17 (2): 327-50.

Eun, Yong-Soo. 2018. "Beyond 'the West/Non-West Divide' in IR: How to Ensure Dialogue as Mutual Learning." The Chinese Journal of International Politics 11 (4): 435-49.

Ge, Zhaoguang. 2015. "Dui tianxia de xianxiang: yige wutuobang beihou de zhengzhi sixiang yu xueshu [Visions of 'Tianxia' - Politics, Ideas, and Scholarship Behind a Utopian Vision]." Reflection, No. 29 (October):1-56.

George, Jim, and David Campbell. 1990. "Patterns of Dissent and the Celebration of Difference: Critical Social Theory and International Relations." International Studies Quarterly 34 (3): 269.

Gladney, Dru C. 1994. "Representing Nationality in China: Refiguring Majority/Minority Identities." The Journal of Asian Studies 53 (1): 92.

Goldstein, Melvyn C. 1997. The Snow Lion and the Dragon: China, Tibet, and the Dalai Lama. Berkeley and Los Angeles; Oxford: University of California Press.

Gonzalez-Vicente, Ruben. 2016. "The Empire Strikes Back? China's New Racial Sovereignty.” Political Geography, 59:139-41.

Groot, Gerry. 2004. Managing Transitions: The Chinese Communist Party, United Front Work, Corporatism, and Hegemony. East Asia. New York: Routledge.

Guo, Yi. 2013. "Tianxia zhuyi: shijie zhixu chongjian de rujia fang'an [Tianxia-ism: A Confucian Solution for Reestablishing World Order].” People's Tribune, No. 6 (March):28-35.

Hardt, Michael, and Antonio Negri. 2000. Empire. Cambridge; Oxford: Harvard University Press.

Hayton, Bill. 2014. The South China Sea: The Struggle for Power in Asia. New Haven, London: Yale University Press.

He, Xinhua. 2006. "Shixi gudai zhongguo de tianxiaguan [A Tentative Discussion of Tianxia Perspective in Ancient China]." Southeast Asian Studies 1 (February): 50-54.

Hellmann, Gunther, and Morten Valbjørn. 2017. "Problematizing Global Challenges: Recalibrating the 'Inter' in IR-Theory." International Studies Review 19 (2): 279-82.

Holbig, Heike. 2014. "Shifting Ideologies of Research Funding: The CPC's National Planning Office for Philosophy and Social Sciences." Journal of Current Chinese Affairs 43 (2): 13-32.

Hollis, Martin, and Steve Smith. 1990. Explaining and Understanding International Relations. New York: Clarendon Press.

Hu, Shaohua. 2006. "Revisiting Chinese Pacifism." Asian Affairs: An American Review 32 (4): 256-78.

Huang, Xiaofeng, Xiongfei Ding, and Jilin Xu. 2012. "Xu Jilin: tan xin tianxia zhuyi [Xu Jilin on New Tianxia-ism].” Dong Fang Daily, January 14. http://www.aisixiang.com/data/49462.html. 
Hui, Victoria Tin-bor. 2005. War and State Formation in Ancient China and Early Modern Europe. New York, NY: Cambridge University Press.

Hui, Victoria Tin-bor. 2012. "History and Thought in China's Traditions." Journal of Chinese Political Science 17 (2): 125-41.

Hurrell, Andrew. 2016. “Beyond Critique: How to Study Global IR?” International Studies Review 18 (1): $149-51$.

Jeffreys, Elaine. 2006. Sex and Sexuality in China. London; New York: Routledge.

Jenco, Leigh K. 2017. "On the Possibility of Chinese Thought as Global Theory." In Chinese Thought as Global Theory: Diversifying Knowledge Production in the Social Sciences and Humanities, edited by Leigh K. Jenco, 1-20. SUNY Series in Chinese Philosophy and Culture. Albany: State University of New York Press.

Jiang, Xiyuan. 2007. "Cong tianxia zhuyi dao hexie shijie: zhongguo waijiao zhexue xuanze jiqi shijian yiyi [From Tianxia-ism to Harmonious World: the Choice of China's Diplomatic Philosophy and Its Practical Implications]." Foreign Affairs Review 97 (August): 46-53.

Johnston, Alastair Iain. 1998. Cultural Realism: Strategic Culture and Grand Strategy in Chinese History. Princeton: Princeton University Press.

Kaltman, Blaine. 2014. Under the Heel of the Dragon: Islam, Racism, Crime, and the Uighur in China. Ohio University Research in International Studies: Global and Comparative Studies Series 7. Athens: Ohio University Press.

Kang, David C. 2008. China Rising: Peace, Power, and Order in East Asia. New York: Columbia Univ. Press.

Katzenstein, Peter J. 1996. The Culture of National Security: Norms and Identity in World Politics. New York: Columbia University Press.

Katzenstein, Peter J. 2016. “Diversity and Empathy.” International Studies Review 18 (1): 151-53.

Kelly, Robert E. 2012. “A 'Confucian Long Peace' in Pre-Western East Asia?” European Journal of International Relations 18 (3): 407-30.

Keohane, Robert O. 1984. After Hegemony: Cooperation and Discord in the World Polit. Economy. Princeton, NJ: Princeton University Press.

Keohane, Robert O., and Joseph S. Nye. 2012. Power and Interdependence. 4. ed. Longman Classics in Political Science. Boston: Longman.

Kim, Hun Joon. 2016. "Will IR Theory with Chinese Characteristics Be a Powerful Alternative?" The Chinese Journal of International Politics 9 (1): 59-79.

Kristensen, Peter M. 2015. "How Can Emerging Powers Speak? On Theorists, Native Informants and Quasi-Officials in International Relations Discourse." Third World Quarterly 36 (4): 637-53.

Kristensen, Peter M., and Ras T. Nielsen. 2013. "Constructing a Chinese International Relations Theory: A Sociological Approach to Intellectual Innovation.” International Political Sociology 7 (1): 19-40.

Latham, Michael E. 2000. Modernization as Ideology: American Social Science and "Nation Building" in the Kennedy Era. The New Cold War History. Chapel Hill; London: The University of North Carolina Press.

Leibold, James. 2007. Reconfiguring Chinese Nationalism: How the Qing Frontier and Its Indigenes Became Chinese. New York: Palgrave Macmillan US.

Lin, Hsiao-ting. 2006. Tibet and Nationalist China's Frontier: Intrigues and Ethnopolitics, 1928-49. UBC Press.

Ling, L. H. M., and Boyu Chen. 2018. "International Relations and the Rise of Asia: A New 'Moral Imagination' for World Politics?" In The Sage Handbook of the History, Philosophy and Sociology of International Relations, edited by Andreas Gofas, Inanna Hamati-Ataya, and Nicholas Greenwood Onuf, 134-47. Los Angeles: Sage.

Liu, Xiaoyuan. 2010. Recast All under Heaven: Revolution, War, Diplomacy, and Frontier China in the 20th Century. New York, NY: Continuum.

Lu, Mingjun. 2016. "The Bene-Ideal: China's Cosmopolitan Vision of World Order." Chinese Political Science Review 1 (2): 336-52.

Lu, Peng. 2019. "Chinese IR Sino-Centrism Tradition and Its Influence on the Chinese School Movement." The Pacific Review 32 (2): 150-67.

Lu, Zhaojin. 2017. "The Changing Definition of China in Middle School History Textbooks: The Changing Definition of China." Nations and Nationalism 23 (3): 571-98.

Lv, Yong. 2007. "Wu lichang yu zhongguo lichang: ping zhao tingyang tianxia tixi shijie zhidu zhexue daolun [Null Standpoint and China's Standpoint - A Review of Zhao Tingyang's Tianxia System: An Introduction to a Philosophy of World Regime]." Journal of Guangxi University 29 (S2):259-60. 
MacKay, Joseph. 2019. "Rethinking Hierarchies in East Asian Historical IR." Journal of Global Security Studies 4 (4): 598-611.

Makarychev, Andrey, and Viatcheslav Morozov. 2013. "Is 'Non-Western Theory' Possible? The Idea of Multipolarity and the Trap of Epistemological Relativism in Russian IR." International Studies Review 15 (3): 328-50.

Mearsheimer, John J. 2001. The Tragedy of Great Power Politics. New York; London: W. W. Norton \& Company.

Milliken, Jennifer. 1999. "The Study of Discourse in International Relations: A Critique of Research and Methods." European Journal of International Relations 5 (2): 225-54.

Nandy, Ashis. 1987. "Cultural Frames for Social Transformation: A Credo." Alternatives: Global, Local, Political 12 (1): 113-23.

Noakes, Stephen. 2014. "The Role of Political Science in China: Intellectuals and Authoritarian Resilience." Political Science Quarterly 129 (2): 239-60.

Noesselt, Nele. 2012. “Is There a 'Chinese School' of IR?" GIGA Working Paper, No. 188:28.

Noesselt, Nele. 2015. "Revisiting the Debate on Constructing a Theory of International Relations with Chinese Characteristics." The China Quarterly 222:430-48.

Norbu, Dawa. 2001. China's Tibet Policy. Durham East Asia Series. Richmond: Routledge.

O'Connor, Alice. 2001. Poverty Knowledge: Social Science, Social Policy, and the Poor in Twentieth-Century U.S. History. Politics and Society in Twentieth-Century America. Princeton, NJ: Princeton University Press.

Oren, Ido. 2003. Our Enemies and US: America's Rivalries and the Making of Political Science. Ithca; London: Cornell University Press.

Owen, Catherine, John Heathershaw, and Igor Savin. 2018. "How Postcolonial Is Post-Western IR? Mimicry and Mētis in the International Politics of Russia and Central Asia." Review of International Studies 44 (02): 279-300.

Ownby, David. 2018. "Editor and Translator's Introduction." In Rethinking China's Rise: A Liberal Critique, edited and translated by David Ownby, ix-xxxii. Cambridge University Press.

Pan, Yihong. 1992. “The Sino-Tibetan Treaties in the Tang Dynasty.” T'oung Pao, Second Series, 78 (1/3): $116-61$.

Pan, Yihong. 1997. "Marriage Alliances and Chinese Princesses in International Politics from Han through T’ang." Asia Major, Third Series, 10 (1/2): 95-131.

Qiao, Taiyun. 2014. "Tianxia tixi yu zhongguo de shijie lixiang [Tianxia System and China's World Vision]." Master Thesis, Beijing: Central Party School of the Communist Party of China.

Qin, Yaqing. 2009. "Development of International Relations Theory in China." International Studies 46 (1-2): 185-201.

Qin, Yaqing. 2018. A Relational Theory of World Politics. New York: Cambridge University Press.

Qu, Pengfei. 2011. "Shixi tianxia zhuyi dui zhongguo gudai zhanlue wenhua de yingxiang [A Brief Discussion of Tianxia-ism's Influence on Ancient Chinese Strategic Culture]." New Heights 30 (4): $105-9$.

Rhoads, Edward J. M. 2000. Manchus \& Han: Ethnic Relations and Political Power in Late Qing and Early Republican China, 1861-1928. Studies on Ethnic Groups in China. Seattle; London: University of Washington Press.

Said, Edward W. 1979. Orientalism. 1st Vintage Books ed. New York: Vintage Books.

Said, Edward W. 1994. Culture and Imperialism. 1st Vintage Books ed. New York: Vintage Books.

Schein, Louisa. 1997. "Gender and Internal Orientalism in China." Modern China 23 (1): 69-98.

Schneider, Florian. 2014. "Reconceptualising World Order: Chinese Political Thought and Its Challenge to International Relations Theory." Review of International Studies 40 (04): 683-703.

Shani, Giorgio. 2008. "Toward a Post-Western IR: The Umma, Khalsa Panth, and Critical International Relations Theory.” International Studies Review 10 (4): 722-34.

Sheng, Hong. 1996. "Cong minzu zhuyi dao tianxia zhuyi [From Nationalism to Tianxia-ism]." Strategy and Management 1 (February): 14-19.

Shih, Chih-yu. 2012. "Assigning Role Characteristics to China: The Role State versus The Ego State: Assigning Role Characteristics to China." Foreign Policy Analysis 8 (1): 71-91.

Song, Xinning. 2001. "Building International Relations Theory with Chinese Characteristics." Journal of Contemporary China 10 (26): 61-74. 
Spivak, Gayatri. 1988. “Can the Subaltern Speak?” In Marxism and the Interpretation of Culture, edited by Cary Nelson and Lawrence Grosberg, 271-314. Urbana \& Chicago: University of Illinois Press.

Tang, Shiping. 2013. The Social Evolution of International Politics. Oxford: Oxford University Press.

Tickner, Arlene B. 2008. "Latin American IR and the Primacy of Lo Práctico." International Studies Review 10 (4): 735-48.

Tickner, Judith Ann. 2016. "Knowledge Is Power: Challenging IR's Eurocentric Narrative." International Studies Review 18 (1): 157-59.

Tsygankov, Andrei P., and Pavel A. Tsygankov. 2010. "National Ideology and IR Theory: Three Incarnations of the 'Russian Idea'." European Journal of International Relations 16 (4): 663-86.

Turton, Helen Louise, and Lucas G Freire. 2017. "Peripheral Possibilities: Revealing Originality and Encouraging Dialogue through a Reconsideration of 'Marginal' IR Scholarship." Journal of International Relations and Development 20 (2): 458-458.

Tuttle, Gray. 2007. Tibetan Buddhists in the Making of Modern China. New York: Columbia University Press.

Valbjørn, Morten. 2017. "Dialoguing about Dialogues: On the Purpose, Procedure and Product of Dialogues in Inter-National Relations Theory." International Studies Review 19 (2): 291-96.

van de Wetering, Carina. 2017. "Policy Discourses and Security Issues: US Foreign Policy Toward India During the Clinton Administration." Foreign Policy Analysis 13 (2): 460-479.

Waltz, Kenneth N. 2001. Man, the State, and War. Revised edition. New York: Columbia University Press. Wang, Hongsheng, and Hao Su. 2015. "Lun zhongxi wenming zhong de tianxiaguan he shijieguan [A Discussion of Tianxia Perspective and World Perspective in Chinese and Western Civilizations]." Journal of Renmin University of China 1 (January): 119-25.

Wang, Q. Edward. 2003. "Encountering the World: China and Its Other(s) in Historical Narratives, 194989." Journal of World History 14 (3): 327-58.

Wang, Yuan-kang. 2011. Harmony and War: Confucian Culture and Chinese Power Politics. Contemporary Asia in the World. New York: Columbia University Press.

Wang, Zheng. 2014. “The Chinese Dream: Concept and Context." Journal of Chinese Political Science 19 (1): $1-13$.

Wendt, Alexander. 1992. "Anarchy Is What States Make of It: The Social Construction of Power Politics." International Organization 46 (02): 391.

Wendt, Alexander. 1999. Social Theory of International Politics. Cambridge Studies in International Relations 67. Cambridge, UK; New York: Cambridge University Press.

Wright, Teresa. 2001. The Perils of Protest: State Repression and Student Activism in China and Taiwan. Honolulu: University of Hawai'i Press.

Xu, Jianxin. 2007. "Tianxia tixi yu shijie zhidu: ping tianxia tixi shijie zhidu zhexue daolun [Tianxia System and World Regime - A Review of Tianxia System: An Introduction to a Philosophy of World Regime]." Quarterly Journal of International Politics 2 (August): 113-42.

Xu, Jilin. 2000. "The fate of an enlightenment: twenty years in the Chinese intellectual sphere (1978-98)." Translated by Geremie R. Barmé and Gloria Davies. East Asian history 20 (December): 169-86.

Xu, Jilin. 2005. "Zhongguo de minzu zhuyi: yige juda er kongdong de fuhao [Chinese Nationalism: A Huge Yet Empty Symbol].” Aisixiang (blog). March 29. http://www.aisixiang.com/data/6241.html.

$\mathrm{Xu}$, Jilin. 2006. "Gonghe aiguo zhuyi yu wenhua minzu zhuyi: xiandai zhongguo liangzhong minzu guojia rentongguan [Republican Patriotism and Cultural Nationalism - Two Types of Nation-State Identification in Modern China]." Journal of East China Normal University (Philosophy and Social Sciences) 38 (4): 1-13.

$\mathrm{Xu}$, Jilin. 2012a. "Rujia xianzheng de xianshi yu lishi [The Reality and History of Confucian Constitutionalism]." Open Times, No. 1 (January):44-59.

Xu, Jilin. 2012b. "Teshu de wenhua haishi xin tianxia zhuyi [Particular Culture or New Tianxia-ism?]." Beijing Cultural Review 2 (April): 20-23.

Xu, Jilin. 2012c. "Tianxia zhuyi yixia zhibian jiqi zai jindai de bianyi [Tianxia-ism/Civilized-Barbarian Distinction and Their Modern Mutation]." Journal of East China Normal University (Philosophy and Social Sciences) 6 (November): 66-75.

$\mathrm{Xu}$, Jilin. 2013a. "Zuowei guozu de zhonghua minzu heshi xingcheng [When Does the Chinese Nation (zhonghua minzu) Constitute a State-Nation (guozu)?]." Journal of Literature, History and Philosophy 3 (May): $128-35$. 
Xu, Jilin. 2013b. "Duoyuan wenming shidai de zhongguo shiming [China's Mission in the Age of Plural Civilizations]." Beijing Cultural Review, No. 3 (June):81-88.

$\mathrm{Xu}$, Jilin. 2015. "Xin tianxia zhuyi: chongjian zhongguo de neiwai zhixu [New Tianxia-ism: Rebuilding China's Internal and External Order]." Intellectuals 13 (August). http://www.aisixiang.com/data/91702. html.

$\mathrm{Xu}$, Jilin. 2016. "Xin tianxia zhuyi: dui minzu zhuyi yu chuantong tianxia zhuyi de shuangchong chaoyue [New Tianxia-ism: Dual Transcendence of Nationalism and Traditional Tianxia-ism]." Exploration and Free Views 5 (May): 62.

$\mathrm{Xu}$, Jilin. 2018. Rethinking China's Rise: A Liberal Critique, edited and translated by David Ownby. Cambridge; New York: Cambridge University Press.

Xu, Jilin. 2019. "I Am a Child of the Nineteenth Century': The Last Twenty Years of Wang Yuanhua's Life (2008)." In Voices from the Chinese Century: Public Intellectual Debate from Contemporary China, edited by Timothy Cheek, David Ownby, and Joshua A. Fogel, translated by David Ownby. New York; Chichester: Columbia University Press.

Xu, Jilin, Tongdong Bai, and Qing Liu. 2015. "Xin tianxia zhuyi sanren tan: dang zhongguo zaoyu shijie [Trio on New Tianxia-ism: When China Encounters the World]." The Paper, March 22. http://www.thepaper.cn/newsDetail_forward_1312217.

Yan, Xuetong. 2011. Ancient Chinese Thought, Modern Chinese Power. Edited by Daniel A. Bell and Zhe Sun. Translated by Edmund Ryden. The Princeton-China Series. Princeton, NJ: Princeton University Press.

Zeng, Xianghong. 2010. "Baquan shijieguan yu guoji guanxi: hexie shijieguan de pipan shiming [Hegemonic Worldview and International Relations - Harmonious Worldview's Duty to Critique]." PhD Thesis, Lanzhou University.

Zhang, Feng. 2011. "The Rise of Chinese Exceptionalism in International Relations." European Journal of International Relations 19 (2): 305-28.

Zhang, Feng. 2012. "The Tsinghua Approach and the Inception of Chinese Theories of International Relations." The Chinese Journal of International Politics 5 (1): 73-102.

Zhang, Feng. 2015. Chinese Hegemony: Grand Strategy and International Institutions in East Asian History. Stanford: Stanford University Press.

Zhao, Tingyang. 2003. “Tianxia tixi: diguo yu shijie zhidu [Tianxia System: Empire and World Regime].” World Philosophy 5 (September): 2-33.

Zhao, Tingyang. 2005. Tianxia tixi: shijie zhidu zhexue daolun [Tianxia System: An Introduction to a Philosophy of World Regime]. Jiangsu Education Publishing House.

Zhao, Tingyang. 2006. “Rethinking Empire from a Chinese Concept 'All-under-Heaven' (Tian-Xia).” Social Identities 12 (1): 29-41.

Zhao, Tingyang. 2007. "Fan zhengzhi de zhengzhi [Anti-Political Politics]." Philosophical Research 12 (December): 30-41, 125.

Zhao, Tingyang. 2008. "Tianxia tixi de yige jianyao biaoshu [A Brief Elaboration of Tianxia System]." World Economics and Politics 10 (October): 57-65.

Zhao, Tingyang. 2009. “A Political World Philosophy in Terms of All-under-Heaven (Tian-xia).” Diogenes 56 (1): 5-18.

Zhao, Tingyang. 2010. “Tianxia tixi de xiandai qishi [The Modern Lesson of Tianxia System]." Beijing Cultural Review 3 (June): 34-41.

Zhao, Tingyang. 2018. "Tianxia jiujing shi shenme? jian huiying sa'erwatuo babonasi de meishi tianxia [What is Tianxia? - A Response to Salvatore Babones's American Tianxia]." Journal of Southwest Minzu University 1 (January): 7-14.

Zhao, Tingyang. 2019. Redefining A Philosophy for World Governance. Translated by Tao. Key Concepts in Chinese Thought and Culture. Singapore: Palgrave Pivot.

Zhao, Tingyang, and Yali Li. 2015. "Xin youxi xuyao xin tixi [New Game Calls for New System]." Journal of International Security Studies 33 (1): 4-13.

Zhao, Tingyang, Jiafan Wang, Dali Yao, Jilin Xu, Yunguo Yu, Tongdong Bai, Qing Liu, et al. 2016. "Tianxia tixi yu weilai shijie zhixu [Tianxia System and the Future World Order]." Exploration and Free Views 5 (May): 52-75.

Zhao, Tingyang, Zhangrun Xu, Jiantao Ren, and Kai Guan. 2018. "Xin tianxia zhuyi zonglun ['A Discussion of 'New Tianxia-ism']." Literature, History, and Philosophy 1 (January): 5-22. 
Zheng, Tiantian. 2009. Ethnographies of Prostitution in Contemporary China: Gender Relations, HIV/AIDS, and Nationalism. New York: Palgrave Macmillan.

Zheng, Yongnian. 2011. "Bianjiang, diyuan zhengzhi he zhongguo de guoji guanxi yanjiu [Frontier, Geopolitics, and China's International Relations Studies]." Foreign Affairs Review 6 (December): 12-20.

Zheng, Yongnian, and Dan Wu. 2014. "Wang Gungwu and the Study of China's International Relations." In Asian Thought on China's Changing International Relations, edited by Niv Horesh and Emilian Kavalski, 54-75. Palgrave Studies in International Relations. Basingstoke; New York: Palgrave Macmillan.

Zhou, Fangyin. 2008. "Tianxia tixi shi zuihao de shijie zhidu ma? Zaiping tianxia tixi shijie zhidu zhexue daolun [Is Tianxia System the Best World Regime? - A Review of Tianxia System: An Introduction to a Philosophy of World Regime]." Quarterly Journal of International Politics 2 (June): 98-104.

Zhu, Qiyong. 2010. "Tianxia zhuyi de kunjing jiqi jindai zaoyu ['The Predicament of 'Tianxia-ism' and Its Modern Experience]." Academic Monthly 42 (1): 49-54.

Zhuang, Liwei. 2005. "Hou xiandai zhuyi yu guoji guanxi yanjiu de qishi [Postmodernism's Lesson for International Relations Studies]." World Economics and Politics 7 (July): 43-49, 5.

Cite this article: Chu, S. 2022. "Whither Chinese IR? The Sinocentric subject and the paradox of Tianxiaism.” International Theory 14 (1), 57-87, doi:10.1017/S1752971920000214 